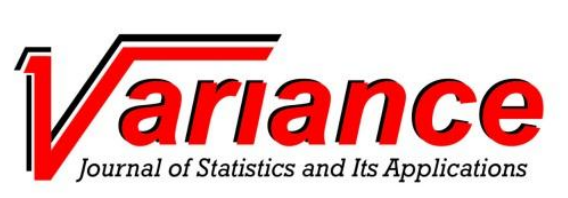

\title{
MISKLASIFIKASI PENJURUSAN MAHASISWA FMIPA UNIVERSITAS PATTIMURA TAHUN AKADEMIK 2016/2017 MENGGUNAKAN METODE ANALISIS DISKRIMINAN BERGANDA
}

\section{Misclassification of Majoring Students of 2016/2017 FMIPA's Students in Pattimura University Using Multiple Discriminant Analysis Method}

\author{
Ferry Kondo Lembang ${ }^{1 *}$, Mozart Winston Talakua ${ }^{2}$, Mega Selvi Hasanudin ${ }^{3}$ \\ ${ }^{1}$ Program Studi Statistika, Jurusan Matematika FMIPA Universitas Pattimura \\ 1,2,3 Jurusan Matematika FMIPA Universitas Pattimura \\ Jl. Ir. M.Putuhena, Kampus Poka - Ambon, 97233, Maluku, Indonesia
}

e-mail corresponding author: ferrykondolembang@gmail.com

\begin{abstract}
Abstrak: Selama ini penjurusan mahasiswa hanya berdasarkan minat mahasiswa pada saat masuk PerguruanTinggi, belum mempertimbangkan prestasi akademik mahasiswa, misalnya nilai mata pelajaran (SMA). Dengan demikian, belum diketahui apakah mahasiswa tersebut benar-benar sesuai untuk masuk jurusan tersebut atau lebih sesuai jika masuk jurusan lainnya. Dalam statistika, masalah seperti ini dapat dipecahkan melalui metode Analisis Diskriminan Berganda yaitu dengan cara menentukan aturan atau kriteria pengelompokkan berdasarkan karakteristik tertentu sehingga kelompok asal dari individu yang bersangkutan dapat ditentukan. Analisis diskriminan merupakan suatu analisis dengan tujuan membentuk sejumlah fungsi melalui kombinasi linear peubah-peubah asal, yang dapat digunakan sebagai cara terbaik untuk memisahkan kelompok-kelompok individu. Fungsi yang terbentuk melalui analisis ini selanjutnya disebut sebagai fungsi diskriminan (Kusumawati, 2002). Dalam penelitian ini ingin diketahui apakah terjadi misklasifikasi dalam penjurusan Mahasiswa FMIPA UNPATTI Tahun Akademik 2016/2017 berdasarkan nilai mata pelajaran MIPA (Nilai UAN dan Raport) dengan menggunakan Analisis Diskriminan. Fungsi diskriminan yang terbentuk, terkait dengan pengelompokkan mahasiswa pada jurusannya, yakni: $\mathrm{y}_{1}=-11,727+0,138 x_{2}+0,044 x_{5}+(-0,039) x_{7} ; \mathrm{y}_{2}=-7,913+0,065 x_{2}+(-0,026) x_{5}+$ $0,070 x_{7} ; y_{3}=7,802+(-0,125)+0,052 x_{5}+(-0,010) x_{7}$. Pengujian validasi pada penelitian diperoleh angka ketepatan fungsi diskriminan sebesar 53\% dari data telah terklasifikasi dengan benar. Hal ini berarti $53 \%$ dari 100 data yang diolah telah dimasukkan pada grup yang sesuai dengan data semula.
\end{abstract}

Kata Kunci: Misklasifikasi, Analisis Diskriminan Berganda, Penjurusan Mahasiswa.

\begin{abstract}
All this time, when entering the tertiary educational institution, the student's breaking up into field process just based on the student's interest, it has not considered the student's academic achievement yet. For example, the school grades (in high school). Therefore, it is unknown whether the students are suitable for that major or more suitable in another major. In statistic, this problem can be solved through discriminant analysis by determinate the rules or grouping's criteria based on the certain characteristic, so that the source group from the related individual can be determined. Discriminant Analysis is an analysis whose purpose to shape a number of functions through the linier combination of source variables that can be used as the best way to separate the individual groups. Then, the shaped functions through this analysis called as Discriminant Function (Kusumati, 2002). In this study wanted to know if there is a misclassification of 2016/2017 FMIPA's students in Pattimura University based on the subjects (UAN and report cards) using discriminant analysis. The discriminant function which shaped, interrelated to the students' grouping in the process of breaking up into the field, they are: $\mathrm{y}_{1}=-11,727+0,138 x_{2}+0,044 x_{5}$ $+(-0,039) x_{7} ; \mathrm{y}_{2}=-7,913+0,065 x_{2}+(-0,026) x_{5}+0,070 x_{7} ; \mathrm{y}_{3}=7,802+(-0,125)+0,052 x_{5}+(-0,010) x_{7}$. Validation testing on research obtained discriminant function accuracy rate of $53 \%$ of the data has been classified correctly. This means that 53\% of 100 processed data has been entered on the group in accordance with the data originally.
\end{abstract}

Keywords: Misclassification, Multiple Discriminant Analysis, Student Majors. 


\section{PENDAHULUAN}

Pemilihan jurusan oleh seorang calon mahasiswa bukanlah hal yang mudah dan dapat diremehkan, karena banyak hal yang harus dipertimbangkan. Akan tetapi tidak sedikit calon mahasiswa tersebut memilih jurusan kuliah hanya asal pilih yang penting bisa kuliah tanpa mempertimbangkan kelanjutannya, baik dalam masa perkuliahan maupun pasca kelulusan. Kesalahan dalam pemilihan jurusan ini disebabkan karena beberapa mindset yang salah dalam memilih jurusan seperti: asal diterima, mengikuti tren jurusan yang banyak dicari dunia kerja, dan bahkan hanya mengikuti pilihan teman. Hal ini dapat menyebabkan rendahnya nilai yang dicapai oleh mahasiswa tersebut sehingga menghambat kelulusan.

Dalam statistika, masalah seperti ini dapat dipecahkan melalui analisis diskriminan yaitu dengan cara menentukan aturan atau kriteria pengelompokkan berdasarkan karakteristik tertentu. Dengan demikian kelompok asal dari individu yang bersangkutan dapat ditentukan. Fungsi diskriminan akan memberikan nilai-nilai yang sedekat mungkin dalam kelompok dan sejauh mungkin antar kelompok. Manfaat lain dari fungsi diskriminan ini disamping dapat digunakan untuk menerangkan perbedaan antar kelompok juga dapat digunakan dalam masalah klasifikasi. Salah satu permasalahan khusus yang berhubungan dengan analisis diskriminan adalah masalah salah pengelompokkan (misklasifikasi) awal pengelompokkan. Sistem ini diharapkan dapat menjadi simulator dalam pemilihan jurusan di FMIPA. Dengan demikian diharapkan tidak ada lagi mahasiswa yang merasa salah jurusan dan dapat mengoptimalkan indeks prestasi dikarenakan sesuai dengan kemampuan akademisnya.

Analisis diskriminan merupakan teknik menganalisis data, dengan variabel tak bebas (criterion) merupakan kategori (non-metrik, nominal atau ordinal, bersifat kualitatif) sedangkan variabel bebas sebagai prediktor merupakan metrik (interval atau rasio, bersifat kuantitatif). Metode fungsi diskriminan pada awalnya dikembangkan oleh Ronald A. Fisher pada tahun 1936 [1], sehingga fungsi diskriminan yang dibangun itu sering pula disebut sebagai fungsi diskriminan linier Fisher. Dalam sebuah paper yang berjudul: "The Use of Multiple Measurements in Taxonomic Problems", Fisher menyatakan bahwa apabila dua atau lebih populasi diukur dalam beberapa karakter $X_{1}, X_{2}, \ldots, X_{p}$, maka dapat dibangun fungsi linier tertentu dari pengukuran itu dimana fungsi itu merupakan fungsi pembeda (pemisah) terbaik bagi populasi-polulasi yang dipelajari. Fungsi linier yang dibangun itu disebut sebagai fungsi diskriminan (diskriminant function) [2].

Menurut [3], terdapat dua tujuan utama pemisahan kelompok dalam analisis diskriminan yaitu: aspek deskriptif dan aspek prediksi. Aspek deskriptif menggambarkan pemisahan kelompok, dimana fungsi linier variabel (fungsi diskriminan) digunakan untuk mendeskripsikan atau menjelaskan perbedaan antara dua atau beberapa kelompok, sedangkan aspek prediksi yaitu mengelompokkan pengamatan kedalam kelompok, dimana fungsi linier atau kuadratik dari beberapa variabel digunakan untuk menentukan suatu sampel individu atau objek kedalam salah satu dari beberapa kelompok.

Penelitian tentang analisis diskriminan terkait misklasifikasi penjurusan mahasiswa pernah diteliti Kusumawati (2002) melalui penulisan tugas akhir Skripsi yang berjudul Analisis Diskriminan Untuk Melihat Misklasifikasi Mahasiswa FMIPA Angkatan 1998/1999 Universitas Jember [4]. Penelitian sejenis juga pernah diteliti Yuana dalam [5] tentang pengelompokkan jurusan mahasiswa FMIPA UNMUL Samarinda dengan melihat nilai mata pelajaran SMA dan nilai mata kuliah pada awal semester. Penelitian lainnya juga pernah dilakukan oleh [6] mengenai analisisis diskriminan kuadratik pada penjurusan Madrasah Aliyah Negeri (MAN) 1 Jember. [7] tentang analisis faktor-faktor yang mempengaruhi kepuasan pelanggan internet speedy reguler menggunakan analisis diksriminan di Semarang.

Tujuan analisis diskriminan yaitu untuk mengklasifikasi atau mengelompokkan suatu individu atau objek kedalam kelompok yang saling bebas dan menyeluruh berdasarkan beberapa faktor penjelas. Lebih lanjut dapat dipelajari dalam [8]). Sementara proses dasar dari analisis diskriminan dapat dipelajari dalam [9]. Analisis diskriminan tidak terlalu sensitif dengan pelanggaran asumsi yang sering digunakan, kecuali pelanggarannya bersifat ekstrim [10]. Meski demikian lebih baik semua asumsi tersebut terpenuhi. 
Jumlah sampel yang ideal pada analisis diskriminan secara pasti tidak ada. Pedoman yang bersifat umum menyatakan untuk setiap variabel independen sebaiknya ada 5-20 data (sampel). Dengan demikian, jika ada enam variabel independen, seharusnya minimal ada sampel. Secara terminologi SPSS, jika ada enam kolom variabel independen, sebaiknya ada 30 baris data.

\section{METODOLOGI}

\subsection{Sumber Data}

Sumber data dalam penelitian ini adalah data sekunder dari FMIPA UNPATTI. Data sekunder pada penelitian ini berasal dari nilai mata pelajaran SMA (nilai UAN dan nilai Raport kelas 3 semester terakhir) mahasiswa FMIPA tahun akademik 2016/2017.

\subsection{Sampel}

Sampel yang digunakan dalam penelitian ini adalah 100 mahasiswa FMIPA UNPATTI Tahun Akademik 2016/2017. Sampel terdiri dari 34 mahasiswa dari Jurusan Matematika, 18 mahasiswa dari Jurusan Fisika, 19 mahasiswa dari Jurusan Kimia, dan 29 mahasiswa dari Jurusan Biologi. Secara tidak pasti tidak ada jumlah sampel yang ideal pada analisis diskriminan. Pedoman yang bersifat umum menyatakan untuk setiap variabel independen sebaiknya ada 5-20 data (sampel). Dengan demikian, jika ada delapan variabel independen, seharusnya minimal ada 8 x $5=40$ sampel [9].

\subsection{Variabel Penelitian}

Dalam penelitian ini variabel dependen merupakan 4 jurusan pada FMIPA UNPATTI, yaitu Jurusan Matematika, Fisika, Kimia dan Biologi. Sedangkan variabel independennya merupakan nilai mata pelajaran SMA (nilai UAN dan nilai Raport kelas 3 semester terakhir), dimana variabel yang digunakan adalah segugus variabel $\left(\mathrm{X}_{1}, \mathrm{X}_{2}, \ldots, \mathrm{X}_{8}\right)$. Variabel dalam proses pengklasifikasian adalah kemampuan akademik yaitu nilai mata pelajaran MIPA (nilai UAN dan nilai Raport kelas 3 semester terakhir), yaitu:

$\mathrm{X}_{1}$ : Nilai UAN Matematika untuk semua jurusan

$\mathrm{X}_{2}$ : Nilai Raport Matematika untuk semua jurusan

$\mathrm{X}_{3}$ : Nilai UAN Fisika untuk semua jurusan

$\mathrm{X}_{4}$ : Nilai Raport Fisika untuk semua jurusan

$\mathrm{X}_{5}$ : Nilai UAN Kimia untuk semua jurusan

$\mathrm{X}_{6}$ : Nilai Raport Kimia untuk semua jurusan

$\mathrm{X}_{7}$ : Nilai UAN Biologi untuk semua jurusan

$\mathrm{X}_{8}$ : Nilai Raport Biologi untuk semua jurusan

\subsection{Langkah-langkah dan Metode Penelitan}

Metode rancangan penelitian yang digunakan pada penelitian ini termasuk penelitian deskriptif, karena bertujuan untuk mendeskripsikan hasil analisis diskriminan yaitu pengklasifikasian mahasiswa FMIPA tahun akademik 2016/2017 UNPATTI untuk menentukan jurusan berdasarkan nilai mata pelajaran SMA (nilai UAN dan nilai Raport kelas 3 semester terakhir) mahasiswa pada jurusan tertentu. Dari nilai tersebut dapat diperoleh informasi jurusan mana yang tepat untuk masing-masing mahasiswa.

Secara umum, langkah-langkah yang dilakukan dalam analisis diskriminan dapat dilihat pada kerangka kerja berikut. 


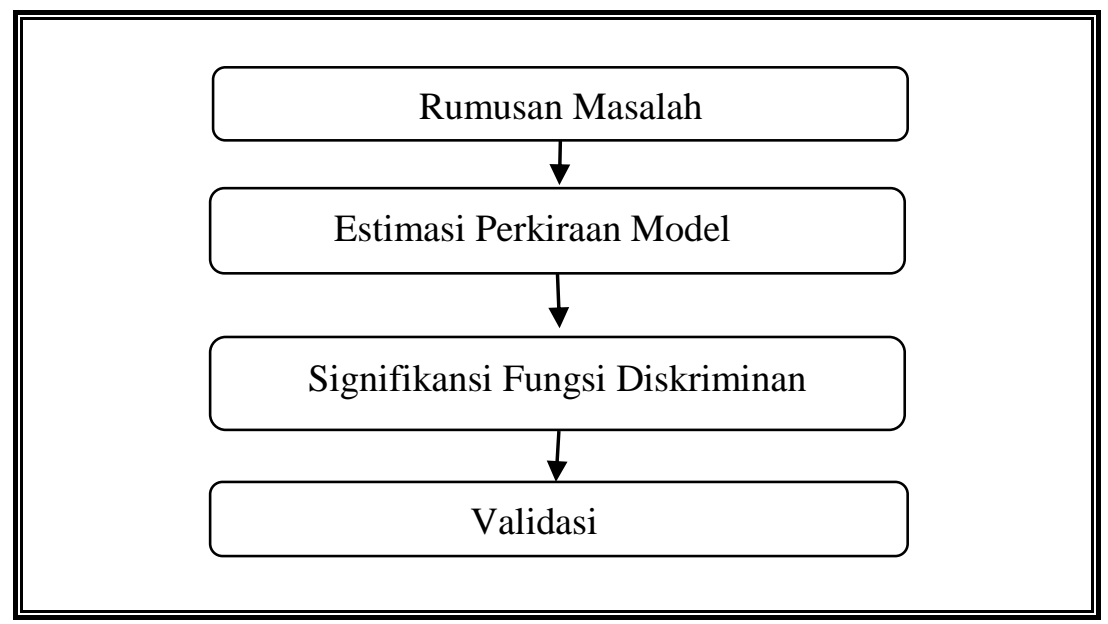

Gambar 1. Langkah-langkah dalam Metode Analisis Diskriminan

\section{HASIL DAN PEMBAHASAN}

\subsection{Pengujian Asumsi}

\subsubsection{Uji Normalitas}

Uji normalitas pada multivariat bisa dilakukan pada setiap variabel dengan logika bahwa jika secara individual masing-masing variabel memenuhi asumsi normalitas, maka secara bersama-sama (multivariat) variabel-variabel tersebut juga bisa dianggap memenuhi asumsi normalitas. Hipotesis yang digunakan dalam pengujian ini adalah:

$\mathrm{H}_{\mathrm{o}}$ : Variabel independen berdistribusi normal

$\mathrm{H}_{1}$ : Variabel independen tidak berdistribusi normal

Tabel 1. One-Sampel Kolmogrov-Smirn
\begin{tabular}{|l|c|}
\hline \multicolumn{1}{|c|}{ Variabel } & Sig. \\
\hline Nilai UAN Matematika & 0,178 \\
\hline Nilai Raport Matematika & 0,626 \\
\hline Nilai UAN Fisika & 0,066 \\
\hline Nilai Raport Fisika & 0,669 \\
\hline Nilai UAN Kimia & 0,166 \\
\hline Nilai Raport Kimia & 0,835 \\
\hline Nilai Uan Biologi & 0,150 \\
\hline Nilai Raport Biologi & 0,709 \\
\hline
\end{tabular}

Sumber: Hasil olahan SPSS 16

Dari hasil uji normalitas dengan menggunakan uji Kolmogorov-Smirnov diperoleh nilai sig. dari kedelapan variabel independen lebih besar dari nilai alpha 0,05. Maka keputusan yang diambil adalah terima $\mathrm{H}_{0}$. Artinya variabel-variabel independen tersebut berdistribusi normal. Sehingga variabel-variabel independen tersebut telah memenuhi asumsi kenormalan dan dapat digunakan untuk analisis diskriminan.

\subsubsection{Uji Kesamaan Matriks Varians-Kovarians}

Pengujian dilakukan untuk menguji varians dari setiap variabel dengan menggunakan uji Box'M. Asumsi yang harus terpenuhi adalah group variance matrices setiap variabel relatif sama. Hipotesis yang digunakan adalah: 
Kondo Lembang dan Hasanudin | Analisis Diskriminan untuk Melihat Misklasifikasi...

$\mathrm{H}_{0}$ : group covariance matrices adalah relatif sama.

$\mathrm{H}_{1}$ : group covariance matrices adalah berbeda secara nyata.

Tabel 2. Test Result

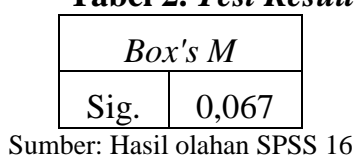

Dari hasil uji kesamaan matriks varians-kovarians diperoleh nilai sig. pada tabel Test Result sebesar 0,067 lebih besar dari nilai alpha 0,05 . Keputusan yang diambil adalah terima $\mathrm{H}_{0}$, artinya asumsi grup kovarians matriks relatif sama telah terpenuhi.

\subsubsection{Uji Korelasi Antar Variabel Independen}

Pengujian dilakukan untuk mengetahui apakah ada multikolinieritas pada data. Asumsi yang harus terpenuhi adalah tidak ada korelasi antara dua variabel independen. Jika dua variabel independen mempunyai korelasi yang kuat, maka dikatakan terjadi multikolinieritas. Signifikansi bisa ditentukan lewat baris Sig. (2-tailed) $<0,05$. Maka hubungan yang terdapat pada $r$ dianggap signifikan.

Tabel 3. Correlation

\begin{tabular}{|c|c|c|c|c|c|c|c|c|c|}
\hline & & $X_{1}$ & $X_{2}$ & $X_{3}$ & $\mathrm{X}_{4}$ & $X_{5}$ & $\mathrm{X}_{6}$ & $\mathrm{X}_{7}$ & $\mathrm{X}_{8}$ \\
\hline \multirow{2}{*}{$\mathrm{X}_{1}$} & $\mathrm{r}$ & \multirow{2}{*}{1} & 0,238 & 0,632 & 0,281 & 0,718 & 0,161 & 0,675 & 0,322 \\
\hline & sig. & & 0,017 & 0,000 & 0,005 & 0,000 & 0,109 & 0,000 & 0,001 \\
\hline \multirow{2}{*}{$\mathrm{X}_{2}$} & $\mathrm{r}$ & 0,238 & \multirow{2}{*}{1} & 0,220 & 0,744 & 0,291 & 0,811 & 0,1136 & 0,706 \\
\hline & sig. & 0,017 & & 0,028 & 0 & 0,003 & 0,000 & 0,177 & 0,000 \\
\hline \multirow{2}{*}{$X_{3}$} & $\mathrm{r}$ & 0,632 & 0,220 & \multirow{2}{*}{1} & 0,273 & 0,602 & 0,183 & 0,629 & 0,217 \\
\hline & sig. & 0,000 & 0,028 & & 0,006 & 0,000 & 0,068 & 0,000 & 0,03 \\
\hline \multirow{2}{*}{$\mathrm{X}_{4}$} & $\mathrm{r}$ & 0,0281 & 0,744 & 0,273 & \multirow{2}{*}{1} & 0,329 & 0,745 & 0,216 & 0,801 \\
\hline & sig. & 0,005 & 0,000 & 0,006 & & 0,001 & 0,000 & 0,031 & 0,000 \\
\hline \multirow{2}{*}{$\mathrm{X}_{5}$} & $\mathrm{r}$ & 0,718 & 0,291 & 0,602 & 0,329 & \multirow{2}{*}{1} & 0,291 & 0,665 & 0,339 \\
\hline & sig. & 0,000 & 0,003 & 0,000 & 0,001 & & 0,003 & 0,000 & 0,001 \\
\hline \multirow{2}{*}{$X_{6}$} & $\mathrm{r}$ & 0,161 & 0,812 & 0,183 & 0,745 & 0,291 & \multirow{2}{*}{1} & 0,118 & 0,757 \\
\hline & sig. & 0,109 & 0,000 & 0,068 & 0,000 & 0,003 & & 0,243 & 0,000 \\
\hline \multirow{2}{*}{$X_{7}$} & $\mathrm{r}$ & 0,675 & 0,136 & 0,629 & 0,216 & 0,665 & 0,118 & \multirow{2}{*}{1} & 0,216 \\
\hline & sig. & 0,000 & 0,177 & 0,000 & 0,031 & 0,000 & 0,243 & & 0,031 \\
\hline \multirow{2}{*}{$\mathrm{X}_{8}$} & $\mathrm{r}$ & 0,322 & 0,706 & 0,217 & 0,801 & 0,339 & 0,757 & 0,216 & \multirow{2}{*}{1} \\
\hline & sig. & 0,001 & 0,000 & 0,030 & 0,000 & 0,001 & 0,000 & 0,031 & \\
\hline
\end{tabular}

Dari hasil uji korelasi antar variabel independen diperoleh nilai Correlation antar variabel adalah terdapat 4 korelasi dari 28 korelasi antar variabel independen yang nilai Sig.(2-tailed) $\geq 0,05$. Contoh salah satu adalah variabel nilai UAN matematika $\left(\mathrm{x}_{1}\right)$ dengan variabel nilai Raport Kimia $\left(\mathrm{x}_{6}\right)$ sebesar 0,109 lebih besar dari 0,05 dengan demikian korelasi antar kedua variabel tidak signifikan, artinya terjadi multikolinieritas. Akan tetapi karena sebagian besar nilai Sig.(-tailed) antar variabel independen lebih kecil dari 0,05, maka asumsi tidak terjadi multikolinieritas dapat diterima. Analisis diskriminan tidak terlalu sensitif pada pelanggaran asumsi ini, kecuali pelanggarannya bersifat ekstrim [10]).

\subsubsection{Uji Outlier}

Uji outlier dilakukan dengan membuat nilai z (standarisasi data) yaitu mengubah nilai data semula dalam bentuk z, kemudian menafsirkan nilai z tersebut. Data dikatakan tidak outlier jika nilai z yang 
diperoleh terletak di antara angka $-2,5$ dan 2,5. Berdasarkan hasil output nilai z semua variabel yang diperoleh (data ke-22 dan data ke-81), yang nilainya tidak berada di antara -2,5 dan 2,5. Sehingga dapat disimpulkan bahwa tidak ada data outlier.

\subsection{Proses Melakukan Analisis Diskriminan 3.2.1. Mengidentifikasi Variabel Diskriminan}

Identifikasi variabel independen bertujuan untuk mengetahui apakah delapan variabel independen berbeda secara signifikan untuk menguji perbedaan suatu kategori terhadap kategori yang lain yaitu kategori penjurusan Mahasiswa FMIPA UNPATTI Tahun Akademik 2016/2017 sehingga layak digunakan untuk analisis diskriminan. Hipotesis yang digunakan adalah:

$\mathrm{H}_{0}$ : Variabel tersebut tidak dapat digunakan untuk mengidentifikasi perbedaan antar kategori.

$\mathrm{H}_{1}$ : Variabel tersebut dapat digunakan untuk mengidentifikasi perbedaan antar kategori.

Tabel 4. Test of Equality of Group Means

\begin{tabular}{|l|c|}
\hline \multicolumn{1}{|c|}{ Variabel } & Sig. \\
\hline Nilai UAN Matematika & 0,426 \\
\hline Nilai Raport Matematika & 0,000 \\
\hline Nilai UAN Fisika & 0,089 \\
\hline Nilai Raport Fisika & 0,017 \\
\hline Nilai UAN Kimia & 0,020 \\
\hline Nilai Raport Kimia & 0,005 \\
\hline Nilai UAN Biologi & 0,012 \\
\hline Nilai Raport Biologi & 0,024 \\
\hline Sumber: Hasil olahan SPSS 16
\end{tabular}

Dari hasil Tabel 4, diperoleh enam variabel independen yang layak digunakan untuk proses diskriminan sebab memiliki nilai sig. $<0,05$ yaitu variabel nilai raport Matematika, nilai raport Fisika, nilai UAN Kimia, nilai raport Kimia, nilai UAN Biologi, dan nilai raport Biologi. Keenam variabel ini layak digunakan untuk mengidentifikasi perbedaan antar kategori variabel dependen.

\subsubsection{Proses Menentukan Variabel}

Variabel yang terbentuk merupakan variabel yang signifikan dan dapat dimasukkan dalam persamaan diskriminan. Oleh karena proses pendekatannya menggunakan Step-Wise Estimation, maka akan dimulai dengan melihat variabel yang mempunyai F hitung (Statistic) terbesar pada output SPSS. Rincian output-nya dapat dilihat dari Tabel 5, yang menyajikan variabel mana saja dari enam variabel yang dapat dimasukkan (entered) dalam persamaan diskriminan.

Tabel 5. Variabel Entered/Removed ${ }^{a, b, c, d}$

\begin{tabular}{|c|l|c|}
\hline Step & \multicolumn{1}{|c|}{ Entered } & Statistic \\
\hline 1 & Nilai Raport Matematika & 0,281 \\
\hline 2 & Nilai UAN Biologi & 2,109 \\
\hline 3 & Nilai UAN Kimia & 1,835 \\
\hline
\end{tabular}

Karena proses adalah stepwise (bertahap), maka akan dimulai dengan variabel yang mempunyai angka $F$ hitung (statistik) terbesar. Tahap pertama angka $F$ hitung variabel nilai UAN Biologi adalah yang terbesar, yakni mencapai 2,109 maka pada tahap pertama ini variabel nilai UAN Biologi terpilih. Tahap kedua angka $F$ hitung variabel nilai UAN Kimia adalah kedua terbesar, yakni mencapai 1,835 maka pada tahap kedua ini variabel nilai UAN Kimia terpilih. Pada tahap ketiga angka F hitung variabel nilai raport Matematika adalah ketiga terbesar, yakni mencapai 0,281 maka pada tahap ketiga ini variabel nilai raport Matematika terpilih. 
Rincian dari proses Step-Wise dapat dilihat pada Tabel 6. Pada tahap pertama variabel nilai raport Matematika adalah variabel pertama yang masuk ke dalam model diskriminan. Hal ini disebabkan variabel tersebut mempunyai angka Sig. of $F$ to Remove yang paling sedikit, yaitu 0,000. Kemudian pada tahap kedua, dimasukkan variable kedua yaitu nilai UAN Biologi. Variabel tersebut memenuhi syarat dengan angka Sig. of $F$ to Remove dibawah 0,05 yaitu 0,016. Pada tahap ketiga atau terakhir, dimasukkan variable Nilai UAN Kimia. Variabel tersebut juga memenuhi syarat dengan angka Sig. of $F$ to Remove di bawah 0,05 yaitu 0,016 .

Tabel 6. Variables in the Analysis

\begin{tabular}{|cl|c|}
\hline & Step & Sig of F to Remove \\
\hline 1 & Nilai Raport Matematika & 0,000 \\
\hline 2 & Nilai Raport Matematika & 0,000 \\
& Nilai UAN Biologi & 0,016 \\
\hline 3 & Nilai Raport Matematika & 0,004 \\
& Nilai UAN Biologi & 0,001 \\
& Nilai UAN Kimia & 0,16 \\
\hline
\end{tabular}

Sumber: Hasil olahan SPSS 16

\subsubsection{Menentukan Signifikansi Fungsi Diskriminan}

Mengukur keeratan hubungan antara discriminant score dengan kategori penjurusan Mahasiswa FMIPA UNPATTI Tahun Akademik 2016/2017 dilihat dari Tabel 7. Ukuran skala asosiasi 0 sampai 1. Semakin tinggi nilai Canonical Correlation maka semakin baik fungsi tersebut menjelaskan variabel yang diamati.

Tabel 7. Eigenvalues

\begin{tabular}{|c|c|}
\hline Function & Canonical Correlation \\
\hline 1 & 0,490 \\
\hline 2 & 0,361 \\
\hline 3 & 0,054 \\
\hline
\end{tabular}

Dari tabel di atas dapat dilihat angka Canonical Correlation yang mengukur keeratan hubungan antara discriminant score dengan grup (dalam hal ini karena ada empat jurusan maka ada empat grup). Angka 0,490 menunjukkan keeratan yang cukup tinggi, dengan ukuran skala asosiasi antara 0 sampai 1. Begitu pula dengan angka 0,361 pada fungsi kedua. Dan walaupun angka Canonical Correlation pada fungsi ketiga dengan grup adalah lemah $(0,054)$, namun ketiga fungsi tetap digunakan untuk interpretasi selanjutnya.

Perbedaan rata-rata variabel diskriminan untuk menentukan signifikansi fungsi diskriminan dapat diketahui melalui nilai Wilk's Lambda.

1. Hipotesis

$\mathrm{H}_{0}: \mu_{1}=\mu_{2}=\mu_{3}=\mu_{4}$ (Tidak ada perbedaan rata-rata antara empat kategori).

$\mathrm{H}_{1}: \mu_{1} \neq \mu_{2} \neq \mu_{3} \neq \mu_{4}$ (Ada perbedaan rata-rata antara empat kategori).

Tabel 8. Wilk's Lambda

\begin{tabular}{|l|c|}
\hline Test of Function & Sig. \\
\hline 1 through 3 & 0,000 \\
\hline 2 through 3 & 0,009 \\
\hline 3 & 0,601 \\
\hline
\end{tabular}

Sumber: Hasil olahan SPSS 16 
Dari Tabel 8 dapat dilihat pada baris pertama bahwa untuk ketiga fungsi diskriminan yang terbentuk memiliki nilai sig. $<0,05$ artinya tolak $\mathrm{H}_{0}$. Sehingga terdapat perbedaan yang nyata (signifikan) antara rata-rata (centroid) dari ketiga fungsi diskriminan yang telah terbentuk. Karena terdapat perbedaan yang nyata, maka penjurusan mahasiswa FMIPA Tahun Akademik 2016/2017 untuk empat jurusan memang berbeda atau bisa dikatakan nilai raport matematika, nilai UAN Biologi, dan nilai UAN Kimia dari mahasiswa FMIPA Tahun Akademik 2016/2017 keempat jurusan memang berbeda.

Untuk analisis baris kedua, interpretasinya sama persis dengan baris pertama dimana fungsi diskriminan pertama dikeluarkan, sehingga hanya fungsi kedua dan ketiga yang dilibatkan memiliki nilai sig. $<0,05$ artinya keputusan yang diambil juga tolak $\mathrm{H}_{0}$. Sehingga terdapat perbedaan yang nyata (signifikan) antara rata-rata (centroid) dari dua fungsi diskriminan (fungsi kedua dan ketiga) yang telah terbentuk. Karena terdapat perbedaan yang nyata, maka penjurusan mahasiswa FMIPA Tahun Akademik 2016/2017 untuk tiga jurusan yakni Fisika, Kimia, dan Biologi memang berbeda atau bisa dikatakan nilai raport matematika, nilai UAN Biologi, dan nilai UAN Kimia dari mahasiswa FMIPA Tahun Akademik 2016/2017 untuk ketiga jurusan diatas. Sedangkan apabila hanya melibatkan fungsi ketiga maka keputusan yang diambil adalah Terima $\mathrm{H}_{0}$ sebab nilai sig. $>0,05$. Sehingga tidak terdapat perbedaan yang nyata (signifikan) antara rata-rata (centroid) dari fungsi diskriminan ketiga yang terbentuk. Artinya jika fungsi diskriminan ketiga berdiri sendiri, justru tidak ada perbedaan antara nilai raport matematika, nilai UAN Biologi, dan Nilai UAN Kimia dari mahasiswa FMIPA Tahun Akademik 2016/2017 jurusan Kimia dan Biologi.

\subsubsection{Intepretasi Hasil Analisis Variabel}

Intepretasi hasil dapat diketahui dari korelasi struktur yang menjelaskan korelasi antara variabel independen dengan fungsi diskriminan yang terbentuk. Hal ini bisa dilihat pada Tabel 9.

Tabel 9. Structure Matrix

\begin{tabular}{|l|c|c|c|}
\hline \multirow{2}{*}{ Variabel } & \multicolumn{3}{|c|}{ Function } \\
\cline { 2 - 4 } & 1 & 2 & 3 \\
\hline Nilai Raport Matematika & 0,794 & 0,377 & 0,477 \\
\hline Nilai UAN Biologi & 0,012 & 0,893 & 0,450 \\
\hline Nilai UAN Kimia & 0,511 & 0,393 & 0,765 \\
\hline Sumber: Hasil olahan SPSS 16
\end{tabular}

Tabel 9 menjelaskan korelasi antara variabel independen dengan tiga fungsi diskriminan yang terbentuk. Dari kriteria tersebut, hanya tiga variabel independen yang lolos uji, yakni nilai raport Matematika, nilai UAN Biologi, dan nilai UAN Kimia. Dan jika dilihat dari besar korelasi (abaikan tanda - jika ada):

a. Untuk fungsi pertama

Variabel nilai raport Matematika paling erat hubungannya dengan fungsi diskriminan diikuti oleh variabel nilai UAN Kimia dan nilai UAN Biologi dengan nilai masing-masing 0,794; 0,511; dan 0,012 .

b. Untuk fungsi kedua

Variabel nilai UAN Biologi paling erat hubungannya dengan fungsi diskriminan diikuti oleh variabel nilai UAN Kimia dan nilai Raport Matematika dengan nilai masing-masing 0,893; 0,393; dan 0,377.

c. Untuk fungsi ketiga

Variabel nilai UAN Kimia paling erat hubungannya dengan fungsi diskriminan diikuti oleh variabel nilai Raport Matematika dan nilai UAN Biologi dengan nilai masing-masing 0,765; 0,477; dan 0,450.

Nilai Canonical Correlation pada Tabel 7 adalah untuk menjelaskan seberapa besar variabel memberikan perbedaan penjurusan Mahasiswa FMIPA Tahun Akademik 2016/2017 secara keseluruhan. 
Kondo Lembang dan Hasanudin | Analisis Diskriminan untuk Melihat Misklasifikasi...

Sedangkan, nilai pada Tabel 9 menjelaskan perbedaan penjurusan Mahasiswa FMIPA Tahun Akademik 2016/2017 dari masing-masing variabel.

\subsubsection{Menentukan Fungsi Diskriminan}

Menurut [9], kegunaan fungsi diskriminan adalah untuk mengetahui sebuah case (dalam hal ini seorang mahasiswa) masuk pada grup yang satu ataukah tergolong pada grup yang lainnya.

\section{Tabel 10. Canonical Discriminant Function Coefficients}

\begin{tabular}{|l|c|c|c|}
\hline \multirow{2}{*}{\multicolumn{1}{|c|}{ Variabel }} & \multicolumn{3}{c|}{ Function } \\
\cline { 2 - 4 } & 1 & 2 & 3 \\
\hline Nilai Raport Matematika & 0,138 & 0,065 & $-0,125$ \\
\hline Nilai UAN Kimia & 0,044 & $-0,026$ & 0,052 \\
\hline Nilai UAN Biologi & $-0,039$ & 0,070 & $-0,010$ \\
\hline (Constant) & $-11,727$ & $-7,913$ & 7,802 \\
\hline Sumber: Hasil olahan SPSS 16
\end{tabular}

Berdasarkan Tabel 10, dapat ditulis fungsi diskriminan sebagai berikut:

Fungsi diskriminan 1: $y_{1}=-11,727+0,138_{x_{2}}+0,044_{x_{5}}+(-0,039)_{x_{7}}$

Fungsi diskriminan 2: $y_{2}=-7,913+0,065_{x_{2}}+(-0,026)_{x_{5}}+0,070_{x_{7}}$

Fungsi diskriminan 3: $y_{3}=7,802+(-0,125)_{x_{2}}+0,052_{x_{5}}+(-0,010)_{x_{7}}$

dimana $x_{2}$ adalah variabel nilai raport Matematika, $x_{5}$ adalah variabel nilai UAN Kimia dan $x_{7}$ adalah variabel nilai UAN Biologi.

\subsubsection{Interpretasi Fungsi Diskriminan} berikut:

Sebagai contoh mahasiswa dengan nama CM dari jurusan Matematika mempunyai data sebagai

Nilai Raport Matematika adalah 93,00, Nilai UAN Kimia adalah 70,00 dan Nilai UAN Biologi adalah 40,00 maka:

$$
\begin{aligned}
& \mathrm{y}_{1}=-11,727+(0,138 * 93,00)+(0,044 * 70,00)+(-0,039 * 40,00)=2,627 \\
& \mathrm{y}_{2}=-7,913+(0,065 * 93,00)+(-0,026 * 70,00)+(0,070 * 40,00)=-0,888 \\
& \mathrm{y}_{3}=7,802+(-0,125 * 93,00)+(0,052 * 70,00)+(-0,010 * 40,00)=-0,583
\end{aligned}
$$

Tabel 11. Functions at Group Centroids

\begin{tabular}{|l|c|c|c|}
\hline \multirow{2}{*}{\multicolumn{1}{c|}{ Jurusan }} & \multicolumn{3}{|c|}{ Function } \\
\cline { 2 - 4 } & 1 & 2 & 3 \\
\hline Matematika & 0,683 & $-0,134$ & $-0,028$ \\
\hline Fisika & $-0,215$ & 0,784 & $-0,01$ \\
\hline Kimia & 0,026 & $-0,027$ & 0,108 \\
\hline Biologi & $-0,685$ & $-0,310$ & $-0,025$ \\
\hline
\end{tabular}

Dengan menggunakan Tabel 11, hasil centroid fungsi maka didapatkan:

$$
\begin{aligned}
& y_{11}=0,683 ; y_{21}=-0,215 ; y_{31}=0,026 ; y_{41}=-0,685 \\
& y_{12}=-0,134 ; y_{22}=0,784 ; y_{32}=-0,027 ; y_{42}=-0,310 \\
& y_{13}=-0,028 ; y_{23}=-0,021 ; y_{33}=0,108 ; y_{43}=-0,025
\end{aligned}
$$

Angka centroid ini dimasukkan kedalam fungsi fisher, sebagai berikut :

$$
\mathrm{k}=1=\left(\mathrm{y}_{1}-\mathrm{y}_{11}\right)^{2}+\left(\mathrm{y}_{2}-\mathrm{y}_{12}\right)^{2}+\left(\mathrm{y}_{3}-\mathrm{y}_{13}\right)^{2}=4,655677
$$




$$
\begin{aligned}
& \mathrm{k}=2=\left(\mathrm{y}_{1}-\mathrm{y}_{21}\right)^{2}+\left(\mathrm{y}_{2}-\mathrm{y}_{22}\right)^{2}+\left(\mathrm{y}_{3}-\mathrm{y}_{23}\right)^{2}=11,88392 \\
& \mathrm{k}=3=\left(\mathrm{y}_{1}-\mathrm{y}_{31}\right)^{2}+\left(\mathrm{y}_{2}-\mathrm{y}_{32}\right)^{2}+\left(\mathrm{y}_{3}-\mathrm{y}_{33}\right)^{2}=7,984003 \\
& \mathrm{k}=4=\left(\mathrm{y}_{1}-\mathrm{y}_{41}\right)^{2}+\left(\mathrm{y}_{2}-\mathrm{y}_{42}\right)^{2}+\left(\mathrm{y}_{3}-\mathrm{y}_{43}\right)^{2}=11,614792
\end{aligned}
$$

Dari keempat hasil $\mathrm{k}$ diatas dicari hasil minimum, diperoleh 4,655677 pada kelompok 1 (Jurusan Matematika) artinya mahasiswa dengan nama CM masuk kedalam kelompok pertama yaitu jurusan Matematika.

\subsubsection{Menilai Validasi Analisis Diksriminan}

Setelah fungsi diskriminan diperoleh, kemudian melakukan pengujian klasifikasi fungsi diskriminan, selanjutnya akan dilihat seberapa besar klasifikasi tersebut tepat mengklasifikasikan kategori. Hal ini bisa dilihat pada Table 12 .

Tabel 12. Classification Results ${ }^{b, c}$

\begin{tabular}{|c|l|c|c|c|c|c|}
\hline \multirow{4}{*}{ Original } & \multirow{2}{*}{ Jurusan } & \multicolumn{4}{|c|}{ Predicted Group Membership } & \multirow{2}{*}{ Total } \\
\cline { 2 - 7 } & Matematika & Matematika & Fisika & Kimia & Biologi & \\
\cline { 2 - 7 } & Fisika & 20 & 6 & 4 & 4 & 34 \\
\cline { 2 - 7 } & Kimia & 5 & 12 & 2 & 2 & 18 \\
\cline { 2 - 7 } & Biologi & 4 & 6 & 3 & 16 & 29 \\
\hline
\end{tabular}

Sumber: Hasil Olahan SPSS 16

Terlihat pada bagian original, mahasiswa yang pada awalnya berasal dari jurusan Matematika dan setelah klasifikasi fungsi diskriminan tetap pada jurusan Matematika adalah sebanyak 20 orang. Sedangkan yang awalnya berada pada jurusan Matematika berpindah ke Jurusan Fisika sebanyak 6 orang, Jurusan Kimia sebanyak 4 orang, dan dan jurusan Biologi sebanyak 4 orang. Untuk kategori mahasiswa jurusan Fisika, Kimia, dan Biologi diinterpretasikan sama persis dengan kategori mahasiswa jurusan Matematika. Dengan demikian ketepatan prediksi dari model diskriminan adalah:

$$
\frac{(20+12+5+16)}{100}=\frac{53}{100}=0,53 \text { atau } 53 \%
$$

Semakin tinggi nilai validasi, termasuk cross-validated groups tentu semakin bagus, karena semakin tepat fungsi diskriminan membedakan penjurusan mahasiswa FMIPA Angkatan 2016/2017. Dari hasil validasi diperoleh ketepatan prediksi dari model diskriminan sebesar 53\% artinya fungsi diskriminan yang telah terbentuk sudah cukup layak untuk memprediksi kasus penjurusan Mahasiswa FMIPA UNPATTI ke depannya sebab hasil yang diperoleh telah mencapai lebih dari $50 \%$.

\section{KESIMPULAN}

Berdasarkan hasil analisis untuk mengetahui apakah terjadi misklasifikasi Mahasiswa FMIPA UNPATTI Tahun Akademik 2016/2017 berdasarkan nilai mata pelajaran (nilai UAN dan nilai raport) dengan analisis diskriminan. Dengan bantuan Program SPSS 16 dapat diambil kesimpulan sebagai berikut:

1. Variabel yang membedakan misklasifikasi penjurusan mahasiswa FMIPA Universitas Pattimura Tahun Akademik 2016/2017 adalah adalah variabel nilai raport Matematika $\left(x_{2}\right)$, Variabel nilai UAN Kimia $\left(x_{5}\right)$, dan variabel nilai UAN Biologi $\left(x_{7}\right)$.

2. Terdapat tiga fungsi diskriminan yang terbentuk, terkait dengan pengelompokkan mahasiswa pada jurusannya, yakni:

Fungsi diskriminan 1: $\mathrm{y}_{1}=-11,727+0,138 x_{2}+0,044 x_{5}+(-0,039) x_{7}$

Fungsi diskriminan 2: $\mathrm{y}_{2}=-7,913+0,065 x_{2}+(-0,026) x_{5}+0,070 x_{7}$

Fungsi diskriminan 3: $\mathrm{y}_{3}=7,802+(-0,125)+0,052 x_{5}+(-0,010) x_{7}$ 
Kondo Lembang dan Hasanudin | Analisis Diskriminan untuk Melihat Misklasifikasi...

3. Pengujian validasi pada penelitian diperoleh angka ketepatan fungsi diskriminan sebesar 53\% dari data telah terklasifikasi dengan benar. Hal ini berarti 53\% dari 100 data yang diolah telah dimasukkan pada grup yang sesuai dengan data semula.

\section{DAFTAR PUSTAKA}

[1] R. A. Fisher, "The Use of Multiple Measurements in Txonomic Problems," The Annals of Human Genetics, pp. 181-188, 1936.

[2] V. Gaspersz, Teknik Analisis dalam Penelitian Percobaan, Bandung: Tarsito, 1995.

[3] A. C. Rencher, Methods of Multivariate Analysis, New York: John Wiley \& Sons. Inc., 1995.

[4] R. Kusumawati, "Analisis Diskriminan Untuk Melihat Misklasifikasi Mahasiswa FMIPA Angkatan 1998/1999 Universitas Jember," Fakultas MIPA UNEJ, Jember, 2002.

[5] Y. Endriyanti, "Tinjauan Pustaka," Fakultas MIPA Universitas Mulawarman, Samarinda, 2007.

[6] P. Inda Wati, "Analisis Diskriminan Kuadratik pada Penjurusan Madrasah Aliyah Negeri (MAN) 1 Jember," Jember, 2013.

[7] I. Sulistiyorini, "Analisis Faktor-faktor yang Mempengaruhi Kepuasan Pelanggan Internet Speedy Reguler Menggunakan Analisis Diskriminan di Semarang," Jurusan Matematika Fakultas MIPA Universitas Negeri Semarang, Semarang, 2013.

[8] J. Supranto, Analisis Multivariat Arti dan Interpretasi, Jakarta: 2004, 2004.

[9] Santoso, Aplikasi SPSS pada Statistik Multivariat, Jakarta: PT Elex Media Komputindo, 2002.

[10] Hair, Multivariate Data Analysis, New Jersey: Pretince Hall, 1987.

[11] J. Sarwono, Statistik Itu Mudah: Panduan Lengkap untuk Belajar Komputasi Stastitik Menggunakan SPSS, Yogyakarta: Universitas Atma Jaya, 2009.

[12] Sanstoso, Aplikasi SPSS pada Statistik Multivariat, Jakarta: PT Elex Media Komputindo, 2003. 